\title{
ELECTROPHORETIC ANALYSIS OF SERUM AND URINARY PROTEINS IN THE DIAGNOSIS OF MYELOMATOSIS
}

\author{
BY \\ J. A. OWEN AND W. D. RIDER* \\ From the University of Edinburgh and the Royal Infirmary, Edinburgh
}

(RECEIVED FOR PUBLICATION NOVEMBER 9, 1956)

Electrophoresis, using either the classical method of Tiselius or zone electrophoresis on paper, has been widely employed in the study of serum and urinary proteins in myelomatosis, but so far few investigators have examined the diagnostic value of this procedure. In an attempt to make such an assessment, we have compared critically the results of electrophoretic analyses of serum and urinary proteins with those of other investigations commonly employed in establishing a diagnosis in this disease. Some aspects of this investigation have already been reported (Owen, Rider, and Stewart, 1956).

\section{Methods}

Total protein concentrations in plasma or serum were determined by one of two methods: (a) a microKjeldahl method, using a conversion factor of 6.25 ; (b) a colorimetric (biuret) method (Gornall, Bardawill, and David, 1949). For the second method a calibration graph was constructed using sera whose total protein concentrations had been determined by the micro-Kjeldahl method. The two methods applied to the same serum gave results which did not differ materially.

Determination of plasma proteins as two fractions, usually designated "albumin" and "globulin," respectively, was carried out using a micro-Kjeldahl method with sodium sulphite as the fractionating agent (King, 1951).

Urines were examined for the presence of protein by the heat coagulation test and by the salicylsulphonic acid test. Examination for the presence of Bence-Jones protein (protein soluble at $100^{\circ}$ ) was carried out according to the method recommended by Snapper, Turner, and Moscovitz (1953).

Zone electrophoresis of serum and urinary proteins on paper was carried out according to the method described by Owen (1956). This procedure, involving reflection photometry and planimetry, enables the relative concentrations of the main serum protein

* J. A. Owen is now at the Department of Biochemistry, Melbourne University, and W. D. Rider at the Department of Radiotherapy, fractions (albumin, $\alpha_{1}, \alpha_{2}, \beta$, and $\gamma$ globulin) to be calculated, and an estimate of the absolute concentrations of each fraction was obtained from the relative concentration and the total protein concentration. Possible errors in this procedure have previously been discussed (Owen, 1956).

Before electrophoretic analysis urines were dialysed against dextran solution (" dextraven," Benger Laboratories, Ltd., $10 \% \mathrm{w} / \mathrm{v}$ in $0.9 \% \mathrm{w} / \mathrm{v}$ sodium chloride) at $5^{\circ} \mathrm{C}$. for 24 to 48 hours to concentrate the protein present.

The electrophoretic pattern of serum proteins was designated "myeloma" type (a) when a narrow zone of protein was present in a position not normally occupied or in the broad $\gamma$-globulin zone (Fig. 1, C and $\mathrm{D})$, or $(b)$ when a protein fraction normally present as a relatively narrow zone, e.g., $\alpha_{2}$ or $\beta$ globulin, was so increased that it constituted $40 \%$ or more of the total protein (Fig. 1, A and B).

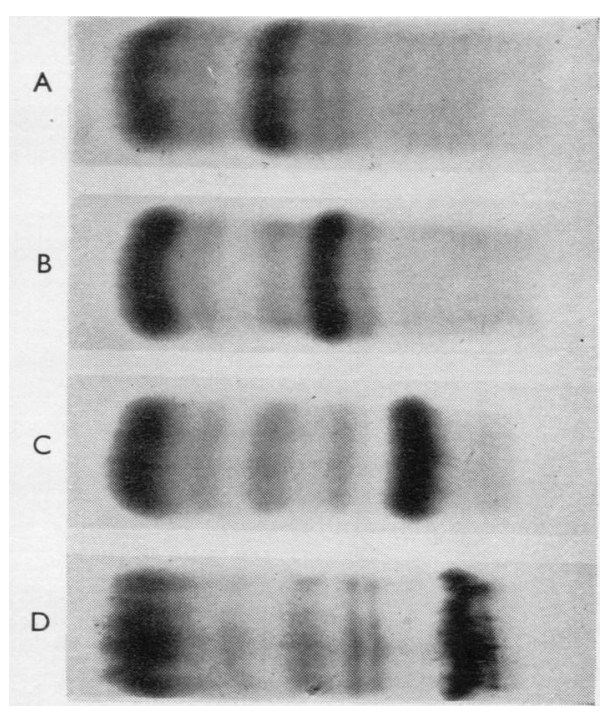

Fig. 1.-Electrophoretic serum protein patterns of the myeloma type. 
Haemoglobin was determined using the alkaline haematin method with optical densities measured on an Eel colorimeter, or using the oxyhaemoglobin method with a " unicam" G.P. photometer. Erythrocyte sedimentation rates (E.S.R.) were measured by means of the Westergren technique without correction for anaemia.

The investigation involved the examination of 40 patients with untreated generalized myelomatosis. Biopsy of bone marrow or tumour confirmed the diagnosis in 33 cases and necropsy in a further two. In the remaining five cases a combination of other findings made the diagnosis practically certain.

\section{Results}

Serum protein patterns of the myeloma type were present in 33 patients, the electrophoretic mobility of the abnormal protein being approximately that of: $\alpha_{2}$ globulin, one case (abnormal protein constituting $43 \%$ of total protein); $\beta$ globulin, five cases $(42-70 \%$ of total protein); $\gamma$ globulin, 27 cases (11-28\% of total protein).

In six of these cases urinary protein was examined. In four cases, the protein migrated mainly as a $\beta$ globulin and was accompanied by traces of albumin and other globulins. In the other two urines, a mixture of proteins, predominantly albumin, was present.

Protein was present in the urine of six of the seven patients whose serum protein patterns were of the non-specific type, i.e., were normal or showed only minor changes.

In five urines almost all the protein migrated as a $\beta$ globulin (Fig. 2). The sixth urine was not examined electrophoretically. Thus, in all the patients with myelomatosis except two either the serum protein pattern was of the myeloma type or the urine protein consisted of a single globulin fraction.

In the course of analysing sera from some 500 other cases, four patients with serum protein patterns of the myeloma type were encountered (Fig. 3). Although certain feature suggest the presence of myelomatosis, a firm diagnosis has not yet been made. The relevant clinical and laboratory data on these cases have been summarized in Table I.

The distribution of haemoglobin values, E.S.R., total plasma protein and plasma globulin concentrations in the patients with myelomatosis are given in Fig. 4. Many patients presented with anaemia and the E.S.R. was elevated in practically every case, although not always markedly. The total protein and globulin concentrations in the plasma were raised in many cases. These results, and other findings, are summarized in Table II.
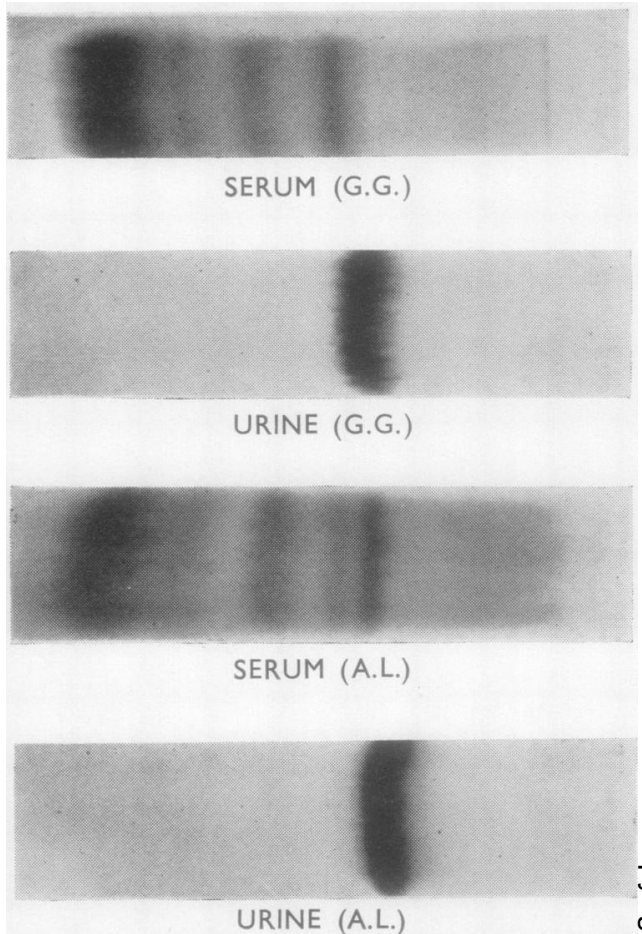

FIG. 2.-Electrophoretic serum protein patterns of the non-specicic type, from two patients with myelomatosis, with the correspond $\bar{\emptyset}$ ing urinary protein patterns.

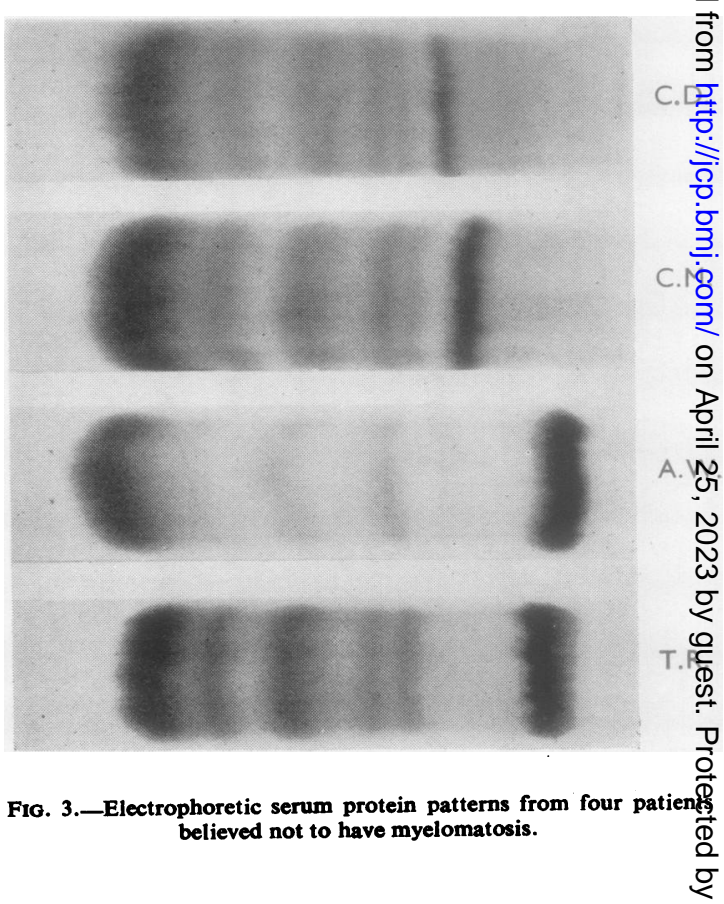


TABLE I

DATA ON PATIENTS WITH FALSE-POSITIVE SERUM PROTEIN PATTERNS

\begin{tabular}{|c|c|c|c|c|c|c|c|c|c|}
\hline Patient & Sex & Age & Clinical Features & $\begin{array}{c}\text { Marrow } \\
\text { Biopsy }\end{array}$ & $\begin{array}{c}\text { Radiological } \\
\text { Bone Changes }\end{array}$ & $\begin{array}{c}\text { E.S.R. } \\
\text { (mm./hr.) }\end{array}$ & $\begin{array}{c}\text { Haemo- } \\
\text { globin } \\
(\mathrm{g} . / 100 \mathrm{ml} .)\end{array}$ & $\begin{array}{c}\text { Plasma } \\
\text { Proteins } \\
\text { Albumin: } \\
\text { Globulin } \\
\text { (g./100 ml.) }\end{array}$ & Proteinuria \\
\hline C.D. & $\mathbf{F}$ & 76 & $\begin{array}{l}\text { Pulmonary infaret; abnor- } \\
\text { mally high sensitivity to } \\
\text { "dindevan" }\end{array}$ & $\begin{array}{r}\text { No increase } \\
\text { in plasma } \\
\text { cells, } \times 1\end{array}$ & Absent & $30-50$ & 15 & $3 \cdot 6 / 1 \cdot 4$ & $\begin{array}{l}\text { Slight; protein } \\
\text { pattern same } \\
\text { as in serum }\end{array}$ \\
\hline C.M. & $\mathbf{M}$ & 73 & $\begin{array}{l}\text { Melaena and haematemesis; } \\
\text { previous history of duo- } \\
\text { denal ulcer }\end{array}$ & $\begin{array}{r}\text { No increase } \\
\text { in plasma } \\
\text { cells, } \times 3\end{array}$ & $\begin{array}{l}\text { ? Paget's disease } \\
\text { of pelvis; other- } \\
\text { wise absent }\end{array}$ & $15-50$ & 13 & $3 \cdot 3 \cdot 2 \cdot 3$ & Absent \\
\hline A.W. & $\mathbf{M}$ & 42 & $\begin{array}{l}\text { Recurrent pneumonia and } \\
\text { pleurisy during } 20 \mathrm{yr} \text {. }\end{array}$ & $\begin{array}{r}\text { No increase } \\
\text { in plasma } \\
\text { cells, } \times 1\end{array}$ & $\begin{array}{l}\text { Cyst in left ilium; } \\
\text { otherwise } \\
\text { absent }\end{array}$ & $\begin{array}{r}\text { Persis- } \\
\text { tently } \\
>100\end{array}$ & 10 & $4 \cdot 0 / 6 \cdot 3$ & ," \\
\hline T.R. & $\mathbf{M}$ & 57 & $\begin{array}{l}\text { Pneumonia with joint pains ; } \\
\text { previous history of pneu- } \\
\text { moconiosis and tuber- } \\
\text { culosis }\end{array}$ & $\begin{array}{l}\text { Slight in- } \\
\text { crease in } \\
\text { plas ma } \\
\text { cells, } \times 1\end{array}$ & Absent & $50-100$ & 14 & $3 \cdot 0 / 2 \cdot 5$ & ", \\
\hline
\end{tabular}

TABLE II

THE INCIDENCE OF POSITIVE FINDINGS IN PATIENTS WITH MYELOMATOSIS

\begin{tabular}{|c|c|c|c|c|c|c|c|c|c|c|c|}
\hline $\begin{array}{l}\text { Serum } \\
\text { Protein } \\
\text { Pattern }\end{array}$ & No. & $\begin{array}{c}\text { Electro- } \\
\text { phoresis } \\
\text { of Serum } \\
\text { Protein } \\
(\%)\end{array}$ & $\begin{array}{c}\text { Electro- } \\
\text { phoresis } \\
\text { of Serum } \\
\text { and } \\
\text { Urinary } \\
\text { Protein } \\
(\%)\end{array}$ & $\begin{array}{c}\text { Positive } \\
\text { Biopsy } \\
(\%)\end{array}$ & $\begin{array}{c}\text { Radio- } \\
\text { logical } \\
\text { Bone } \\
\text { Changes } \\
(\%)\end{array}$ & $\underset{(\%)}{\text { Anaemia }}$ & $\begin{array}{c}\text { Elevation } \\
\text { of } \\
\text { E.S.R. }\end{array}$ & $\begin{array}{c}\text { Pro- } \\
\text { teinuria } \\
(\%)\end{array}$ & $\begin{array}{l}\text { Hyper- } \\
\text { protein- } \\
\text { aemia } \\
(\%)\end{array}$ & $\begin{array}{l}\text { Hyper- } \\
\text { globulin- } \\
\text { aemia } \\
(\%)\end{array}$ & $\begin{array}{l}\text { Bence- } \\
\text { Jones } \\
\text { Protein- } \\
\text { uria } \\
(\%)\end{array}$ \\
\hline $\begin{array}{l}\text { Myeloma type } \\
\text { Non-specific } \\
\text { All .. } \quad .\end{array}$ & $\begin{array}{r}33 \\
7 \\
40\end{array}$ & $\begin{array}{r}100 \\
0 \\
83\end{array}$ & $\begin{array}{r}103 \\
71 \\
95\end{array}$ & $\begin{array}{c}90 * \\
100 \div \\
92\end{array}$ & $\begin{array}{r}81 \\
100 \\
85\end{array}$ & $\begin{array}{l}79 \\
71 \\
80\end{array}$ & $\begin{array}{l}91 \\
14 \\
78\end{array}$ & $\begin{array}{l}65 \dagger \\
84 \\
68\end{array}$ & $\begin{array}{r}68 \\
0 \\
53\end{array}$ & $\begin{array}{r}58 \\
0 \\
49\end{array}$ & $\begin{array}{l}28 \ddagger \\
29 \\
28\end{array}$ \\
\hline
\end{tabular}

* Three patients not examined. One of them and one with negative biopsy had diagnostic necropsy findings. †Two patients not examined. ¥ One patient not examined.

The findings are tabulated as the percentage of patients showing a positive result, according to the following criteria: Electrophoresis of serum proteins, myeloma pattern; electrophoresis of urinary protein, single globulin zone; biopsy, plasmocytosis with sheets of plasma cells; anaemia, Hb $<10 \mathrm{~g} . / 100 \mathrm{ml}$.; elevated E.S.R. $>70 \mathrm{~mm} . / \mathrm{hr}$.; hyperproteinaemia, total plasma protein $>8 \mathrm{~g} . / 100 \mathrm{ml}$.; hyperglobulinaemia, plasma globulin $>5 \mathrm{~g} .100 \mathrm{ml}$.

TABLE III

SUMMARY OF REPORTED FINDINGS IN MYELOMATOSIS

\begin{tabular}{|c|c|c|c|c|c|c|c|c|c|c|}
\hline Author & $\begin{array}{l}\text { Total } \\
\text { No. of } \\
\text { Cases }\end{array}$ & $\begin{array}{c}\text { Specific } \\
\text { Serum } \\
\text { Protein } \\
\text { Pattern } \\
(\%)\end{array}$ & $\begin{array}{c}\text { Positive } \\
\text { Biopsy } \\
\text { (\%) }\end{array}$ & $\begin{array}{c}\text { Radio- } \\
\text { logical } \\
\text { Bone } \\
\text { Changes } \\
(\%)\end{array}$ & $\begin{array}{c}\text { Anaemia } \\
(\%)\end{array}$ & $\begin{array}{c}\text { Elevation } \\
\text { of E.S.R. } \\
\mathbf{( \% )}\end{array}$ & $\begin{array}{l}\text { Protein- } \\
\text { uria } \\
(\%)\end{array}$ & $\begin{array}{l}\text { Hyper- } \\
\text { protein- } \\
\text { aemia } \\
(\%)\end{array}$ & $\begin{array}{l}\text { Hyper- } \\
\text { globulin- } \\
\text { aemia } \\
(\%)\end{array}$ & $\begin{array}{c}\text { Bence- } \\
\text { Jones } \\
\text { Protein- } \\
\text { uria } \\
(\%)\end{array}$ \\
\hline 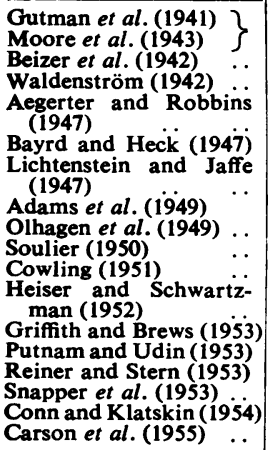 & $\begin{array}{r}43 \\
10 \\
19 \\
13 \\
83 \\
35 \\
30 \\
16 \\
10 \\
8 \\
58 \\
20 \\
24 \\
91 \\
97 \\
18 \\
90\end{array}$ & $\begin{array}{c}82(16) \\
- \\
- \\
- \\
- \\
70 \\
69 \\
90 \\
- \\
77(22) \\
95 \\
83 \\
78 \\
70(43) \\
78 \\
-\end{array}$ & $\begin{array}{c}\overline{80} \\
75(12) \\
= \\
\overline{86} \\
100 \\
33(3) \\
\frac{92}{=} \\
\overline{89} \\
=\end{array}$ & $\begin{array}{c}87(31) \\
70 \\
47 \\
84 \\
78 \\
\overline{86} \\
87 \\
71(5) \\
\frac{87}{=} \\
\overline{87} \\
81 \\
-\end{array}$ & $\begin{array}{c}\overline{90} \\
61 \\
\overline{53^{2}} \\
70 \\
86^{1} \\
\overline{-} \\
25 \overline{(4)} \\
= \\
\bar{z} \\
\overline{-} \\
66^{5}(60)\end{array}$ & $\begin{array}{l}= \\
= \\
= \\
= \\
= \\
=\end{array}$ & $\begin{array}{c}- \\
= \\
83 \\
60(76) \\
= \\
\overline{-} \\
75 \overline{(8)} \\
= \\
\overline{-} \\
\overline{90} \\
76(60)\end{array}$ & $\begin{array}{c}54 \\
85(7) \\
100 \\
38(8) \\
73(36) \\
\overline{52} \\
56 \\
100(8) \\
- \\
\overline{60} \\
75 \\
\overline{72} \\
50 \\
57^{1}(47)\end{array}$ & $\begin{array}{c}42 \\
83(6) \\
- \\
20(5) \\
50^{3}(36) \\
50(16) \\
67 \\
69 \\
85(6) \\
- \\
\overline{55} \\
75 \\
\overline{45^{4}} \\
61 \\
72^{1}(47)\end{array}$ & $\begin{array}{c}45 \\
60 \\
25(12) \\
8 \\
53(76) \\
38(26) \\
47 \\
44 \\
33(3) \\
25 \\
40(25) \\
= \\
40 \overline{(53)} \\
49 \\
32 \\
32(53)\end{array}$ \\
\hline
\end{tabular}

${ }^{1}$ Critical level of abnormality not stated. ${ }^{2} \mathrm{Hb} 11 \mathrm{~g} . / 100 \mathrm{ml}$. or less. ${ }^{3}>6 \mathrm{~g} . / 100 \mathrm{ml}$. ${ }^{4}>7 \mathrm{~g} . / 100 \mathrm{ml}$. ${ }^{5}$ Red cell count, $<4 \times 10^{6} / \mathrm{c} . \mathrm{mm}$.

The findings have been tabulated as in Table II. Where serial observations have been reported the initial values only have been considered. The figures in parenthesis refer to the number of patients examined where this is appreciably different from total number of cases reported. 

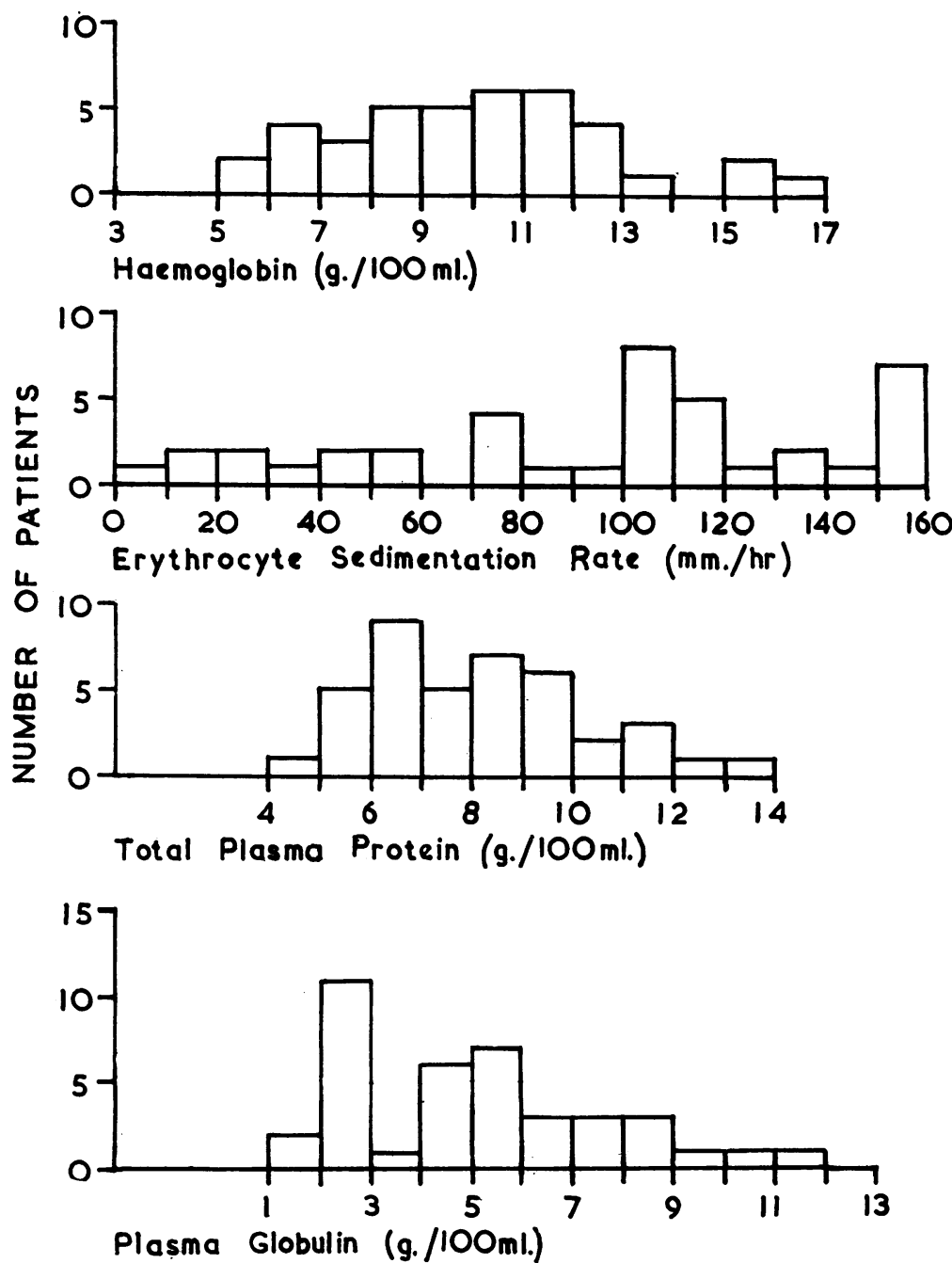

FIG. 4.-Histograms of haemoglobin, E.S.R., total plasma protein, and plasma globulin values in patients with myelomatosis at the time of diagnosis.

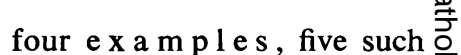
cases, diagnosed respectively as hepatitis, gastric $\mathrm{c} \mathrm{a} \mathrm{r} \mathrm{c} \mathrm{i-} \stackrel{0}{\mathscr{O}}$ noma, cirrhosis, degenerative $\bar{O}$ arthritis, and carcinomatosis with metastases in bone and $\frac{\bar{\rho}}{\partial}$ lungs, were described by $\underset{\mathbb{\Omega}}{\stackrel{2}{ }}$ Adams, Alling, and Lawrence (1949), and Dagnall (1954) has reported a further in- $?$ stance in a patient suffering $\vec{\omega}$ from bronchitis, emphysema, $\stackrel{\circ}{\circ}$ and possibly bronchiectasis (Dagnall, personal communi- $\overrightarrow{\overrightarrow{0}}$ cation). Other false-positive results have been reported $\dot{\omega}$ in patients with conditions $\omega$ which fall into the category 을 "lymphoid reticulosis" (McFarlane, Dovey, Slack, Z a n d Papastamatis, 1952 ; Griffiths and Gilchrist, 1953 ; 3 Griffiths, Gilchrist, King, and Brews, 1954 ; Osserman and Lawlor, 1955; Hutchisoro of 1956). These cases, however may represent an extrems. variety of a disease more commonly presenting as myelomatosis. A myeloma ֶ type serum protein pattern is $\stackrel{\mathbb{Q}}{\varrho}$ also present in macroglobu- $\overrightarrow{\vec{P}}$ linaemia (Waldenström, 1944, 은 1948, 1952; Mandema, van $\vec{J}$ der Schaaf, and Huisman, 1955), a condition characterized by the presence in serum of protein with a high 윽 molecular weight $\left(\mathrm{S}^{20}=20 \mathrm{~S}\right)$. Such protein is stated not to occur in the serum of patients

Cryoglobulins were observed in two sera. A third serum became very viscid at room temperature without the separation of precipitate. In all three sera an abnormal protein, migrating as a $\gamma$ globulin, was present.

\section{Discussion}

Our findings confirm previous reports of characteristically abnormal electrophoretic serum protein patterns in a high percentage of patients with myelomatosis (Table III). In contrast, serum protein patterns of the myeloma type have only rarely been encountered in patients not suffering from myelomatosis. In addition to the present with myelomatosis (Waldenström, 1952 ; Putnam 을 and Udin, 1953) although it was present in the $D$ serum of one patient believed to have myelomatosis described by Mandema et al. (1955). It N is evident from these reports that the myeloma pattern is not specific to myelomatosis.

The urinary proteins of patients with multiple $\omega$ myeloma consist mainly or often entirely of a single globulin fraction migrating as a $\beta$ or $\gamma \stackrel{0}{C}$ globulin. When renal damage is present other $\mathbb{\Phi}$ proteins, including albumin and the serum myeloma protein, appear (Gutman, Moore, Gutman, McClellan, and Kabat, 1941; Moore, $\mathbb{D}$ Kabat, and Gutman, 1943 ; Rundles, Cooper, and 


\section{ELECTROPHORETIC ANALYSIS OF}

Willett, 1951 ; Soulier, 1953 ; Dustin and Vis, 1954 ; Standaert, 1954 ; Slater and Kunkel, 1953 ; Osserman and Lawlor, 1955; ten Thije, 1956). Occasionally two globulin fractions have been noted in the urine. In contrast, the protein which occurs in small amounts in normal urine (Rigas and Heller, 1951; McGarry, Sehon, and Rose, 1955) or that in urine in other diseases, e.g., the nephrotic syndrome, consists of several proteins, including albumin, which usually predominates (Gutman, 1948 ; Soulier, 1953 ; Dustin and Vis, 1954 ; Standaert, 1954 ; Sellers and Marmorston, 1956). Thus it may be concluded from our findings, and from those of others, that a proteinuria in which the urinary protein consists mainly, or even entirely, of one or two globulin fractions is diagnostic of myelomatosis except, rarely, when Bence-Jones proteinuria accompanies some other condition, as is discussed below. This is of particular diagnostic value in cases where the plasma protein patterns show only minor changes, since, in these cases, proteinuria is especially common (Olhagen, Thorell, and Wising, 1949; Janssen, 1951 ; Snapper et al., 1953 ; Putnam and Udin, 1953).

Elevated total plasma protein and globulin levels have been reported in about $50 \%$ of cases (Table III). However, except when the elevation is considerable it is of little diagnostic value since similar findings occur in other conditions. Thus, King (1951) states that $1 \%$ of normal persons have total plasma protein concentrations greater than $8.2 \mathrm{~g} . / 100 \mathrm{ml}$. The examination of plasma proteins in a large series of hospital patients (Owen et al., 1956) revealed that $87 \%$ of the patients with total plasma proteins greater than $8 \mathrm{~g} / 100 \mathrm{ml}$. and $60 \%$ of those with plasma globulin greater than $5 \mathrm{~g} . / 100 \mathrm{ml}$. suffered from diseases other than myelomatosis.

In the present series Bence-Jones protein was detected in only $27 \%$ of urines although the incidence of proteinuria (protein insoluble at $100^{\circ} \mathrm{C}$.) was much higher, as was found by Bayrd and Heck (1947), Soulier (1950), Snapper et al. (1953), and ten Thije (1956). From a practical point of view, the two main criteria on which the usual tests for Bence-Jones protein depend are unreliable. First, precipitation at relatively low temperatures $\left(40^{\circ}-60^{\circ}\right.$ C.) occurs with various other serum and urinary proteins (the pseudoBence-Jones of Snapper et al., 1953). This depends on the $\mathrm{pH}$ (Owen, unpublished data), as may be demonstrated with normal urine to which whole normal serum (assumed to contain negligible amounts of Bence-Jones protein) has been added. Secondily, reversible solution on heating Bence-Jones protein depends rather critically on the presence of other solutes, especially electrolytes (Marrack and Hoch, 1949 ; Soulier, 1953). Further, a considerable difference exists in the physico-chemical properties of the Bence-Jones proteins excreted by different patients (Moore et al., 1943; Rundles et al., 1951 ; Putnam and Stelos, 1953; Deutsch, 1955) so that conditions which are ideal for demonstrating the presence of one Bence-Jones protein may not be suitable for the demonstration of another. We have observed a case in which the urinary protein (a $\beta$ globulin) had a molecular weight of about 35,000 but which did not show heat solubility either in the urine as passed or when isolated and added to normal urine, and similar findings have been reported by Dustin and Vis (1954).

It is concluded that, as an aid to diagnosis, tests for the presence of heat-soluble Bence-Jones protein as usually carried out tend to be of little value because of the technical difficulties discussed above, because of the relatively low incidence of "positive" results in myelomatosis, and because of the occasional "positive" results obtained in other conditions (Geschickter and Copeland, 1928 ; Bayrd and Heck, 1947 ; Reiner and Stern, 1953; see, however, Snapper et al., 1953). Possibly the more sensitive and, presumably more specific, precipitin test (Collier and Jackson, 1953) may be of greater value.

The common occurrence of an elevated E.S.R. and of anaemia requires little comment. It is perhaps of greater importance to emphasize the not infrequent occurrence of relatively low E.S.R. values. In the present series six patients had an E.S.R. less than $40 \mathrm{~mm}$./ hour.

Biopsy of marrow in the sternum or other site, or of tumour if present, is generally considered to be the most reliable single means of diagnosing myelomatosis. However, the diffuse nature of the disease process often makes repeated examinations necessary before a typically abnormal specimen of marrow is obtained, and difficulty in interpreting a moderate increase in the percentage of plasma cells is not infrequent. Further, there are many reports of plasmocytosis in marrow in diseases other than myelomatosis (Marchal and Mallet, 1948 ; Fadem and McBirnie, 1950 : Hayhoe and Smith, 1951 ; Klein and Block, 1953 ; Hughes, 1954).

Over $80 \%$ of patients with myelomatosis show some abnormality on radiological examination. It is generally agreed, however, that there is no single pattern which is diagnostic of the disease (Bayrd 
and Heck, 1947 ; Wallerstein, 1951 ; Heiser and Schwartzman, 1952). The most common appearance, occurring in about $70 \%$ of cases showing some abnormality, consists of multiple osteolytic defects scattered throughout the skeleton and is well known as the "classical" appearance.

\section{Conclusions}

In generalized myelomatosis the combined results of electrophoretic analysis of serum and urinary proteins are "diagnostic" more commonly than those given by any other procedure. Moreover, the specificity of the electrophoretic findings is high.

Biopsy, however, is of greater diagnostic value than analysis of either serum or urinary proteins alone. All other tests commonly employed are of less value.

It is a pleasure to thank Dr. C. P. Stewart for his encouragement, help, and advice, and the many physicians and surgeons for their co-operation in this investigation. Drs. Croft and Mauritzen, of the Biochemistry Department, University of Edinburgh, were kind enough to carry out a molecular weight determination on a Bence-Jones protein. We are indebted to Miss M. Patterson, Miss H. Roulet, and Miss F. Taylor for their technical assistance with the electrophoretic analyses, and also to the Scottish Hospital Endowments Research Trust for a grant enabling Miss Roulet to participate in this work.

\section{REFERENCES}

Adams, W. S., Alling, E. L., and Lawrence, J. S. (1949). Amer. J. Med., 6, 141 .

Aegerter, E., and Robbins, R. (1947). Amer. J. med. Sci., 213, 282 Bayrd, E. D., and Heck, F. J. (1947). J. Amer. med. Ass., 133, 147 Beizer, L. H., Hall, B. E., and Giffin, H. Z. (1942). Amer. J. med. Sci., $203,829$.

Carson, C. P., Ackerman, L. V., and Maltby, J. D. (1955). Amer. J. clin. Path., $25,849$.

Collier, F. C., and Jackson, P. (1953). New Engl. J. Med., 248, 409

Conn, H. O., and Klatskin, G. (1954). Amer. J. Med., 16, 822.
Cowling, D. C. (1951). Med. J. Aust., 1, 655.

Dagnall, P. (1954). Brit. med. J., 1, 644.

Deutsch, H. F. (1955). J. biol. Chem., 216, 97.

Dustin, J. P., and Vis, H. (1954). 2de. Colloquium, Sint-Jans Hospitaal, Brugge, 1954, p. 111.

Fadem, R. S., and McBirnie, J. E. (1950). Blood, 5, 191.

Geschickter, C. F., and Copeland, M. M. (1928). Arch. Surg. (Chicago), 16, 807.

Gornall, A. G., Bardawill, C. J., and David, M. M. (1949). J. biol. Chem., 177, 751 .

Griffiths, L. L., and Brews, V. A. L. (1953). J. clin. Path., 6, 187. - and Gilchrist, L. (1953). Lancet, 1, 882.

- King, M. B., and Brews, V. A. L. (1954). Ibid., 2, 1286

Gutman, A. B. (1948). Advanc. Protein Chem., 4, 155.

- Moore, D. H., Gutman, E. B., McClellan, V., and Kabat, E. A. (1941). J. clin. Invest., 20, 765 .

Hayhoe, F. G. J., and Smith, D. R. (1951). J. clin. Path., 4, 47.

Heiser, S., and Schwartzman, J. J. (1952). Radiology, 58, 178.

Hughes, J. T. (1954). Brit. med. J., 2, 1267.

Hughes, J. T. (1954). Brit. med. J., 2, 1267. 185.

Hutchison, H. E. (1956). J.clin. Path.,' 185. Verh. Ned. Akad. Wet., Sect. 2 (Afd. Nat.), 47, No. 3.

King, E. J. (1951). Micro-analysis in Medical Chemistry, 2nd ed. Churchill, London.

Klein, H., and Block, M. (1953). Blood, 8, 1034.

Lichtenstein, L., and Jaffe, H. L. (1947). Arch. Path. (Chicago), 44, 207.

McFarlane, A. S., Dovey, A., Slack, H. G. B., and Papastamat is , S. C. (1952). J. Path. Bact., 64, 335.

McGarry, E., Sehon, A. H., and Rose, B. (1955). J. clin. Invest., 34, 832 .

Mandema, E., Schaaf, P. C. van der, and Huisman, T. H. J. (1955) $J$ Lab clin. Med. 45, 261.

Marchal, G., and Mallet, L. (1948). Sang, 19, 457.

Marrack, J. R., and Hoch, H. (1949). J. clin. Path., 2, 161

Moore, D. H., Kabat, E. A., and Gutman, A. B. (1943). J. clin. Invest., 22, 67.

Olhagen, B., Thorell, B., and Wising, P. (1949). Scand. J. clin. Lab Invest., 1, 49.

Osserman, E. F., and Lawlor, D. P. (1955). Amer. J. Med., 18, 462

Owen, J. A. (1956). Analyst, 81, 26.

Rider, W. D., and Stewart, C. P. (1956). 4de Colloquium, Sinto Jans Hospitaal, Brugge, 1956, p. 103.

Putnam, F. W., and Stelos, P. (1953). J. biol. Chem., 203, 347.

- and Udin, B. (1953). Ibid., 202, 727.

Reiner, M., and Stern, K. G. (1953). Acta haemat. (Basel), 8, 19.

Rigas, D. A and Heller, C. G. (1951). J. clin. Invest. $30,853$.

Rundies, R. W., Cooper, G. R., and Willett, R. W. (1951). Ibid.

Sellers, A. L., and Marmorston, J. (1956). J. Lab. clin. Med., 47 248.

Slater, R. J., and Kunkel, H. G. (1953). Ibid., 41, 619.

Snapper, I., Turner, L. B., and Moscovitz, H. L. (1953). Multiple Myeloma. Grune and Stratton, New York.

Soulier, J. P. (1950). Sang, 21, 37.

Stand (1953). Presse méd., 61, 49. 1954, p. 119.

Thije, O. J. ten (1956). Acta med. scand., 153, 253.

Waldenström, J. (1942). Acta chir. scand., 87, 365.

- (1944). Acta med. scand., 117, 216.

(1948). Schweiz. med. Wschr., 78, 927.

(1952). Advanc. intern. Med., $5,398$.

Wallerstein, R.S. (1951). Amer. J. Med., 10, 325. 